\title{
Oepke Noordmans en Paul Scholten
}

\author{
W Balke
}

Ministerie van Onderwijs en Wetenschappen

Nederland

\begin{abstract}
Oepke Noordmans and Paul Scholten

Two prominent figures of this century, Paul Scholten, one of the most outstanding professors of law of his time, and the genial theologian, Oepke Noordmans, corresponded over a long period of time. Scholten was a lawyer with a profound interest in theology, while Noordmans was involved in laying the foundations of church order. Their correspondence affords a special insight into their views on the developments around them in which they themselves played a leading role.
\end{abstract}

De theoloog Oepke Noordmans en de jurist Paul Scholten, ieder baanbrekend op zijn terrein, hebben jarenlang een bijzonder contact met elkaar gehad en ongetwijfeld elkaar beinvloed. De strijd om de reorganisatie van de hervormde kerk en de voorbereiding van de nieuwe kerkorde bracht hen tot elkaar. Het heeft een goede zin naar hun relatie te vragen vooral nu hun correspondentie daartoe belangrijke gegevens aanreikt. Men ziet in de briefwisseling van nabij hoe deze twee beide uitzonderlijk begaafde mensen met elkaar omgaan.

\section{PROF MR PAULUS SCHOLTEN}

Paulus Scholten (1875-1946), vanaf 1907 hoogleraar te Amsterdam, was én der meest vooraanstaande rechtsgeleerden in Nederland in deze eeuw (Bregstein 1945/ 1946:327v). Scholten stamde niet uit een positief christelijk milieu en kwam eerst op latere leeftijd tot de kerk. God was voor hem oorsprong en bron van het recht. 
Daarom moet het positieve recht steeds worden getoetst aan de Goddelijke gerechtigheid, zoals deze in deze wereld in Jezus Christus gestalte heeft gekregen. 'Zijn diep religieus besef...doet hem overtuigd zijn van de gebrekkigheid der menselijke hulpmiddelen tot verwesenlijking der gerechtigheid. Hij is diep doordrongen van onze menselijke beperktheid: hy was een ootmoedig mens' (Bregstein 1945/1946: 336). Bij zijn afscheid van de universiteit van Amsterdam zei Scholten:

Een college is niet de plaats voor een geloofsbelijdenis. Ik heb er mij altijd van onthouden, al heb ik mijn overtuiging niet verdoezeld. Ik zal ook nu geen confessie uitspreken. Gij weet, dat ik een man ben van positief-Christelijke, reformatorische overtuiging. Gij begrijpt, hoop ik, dat ik krachtens die overtuiging alleen dan een toekomst voor het Nederlandsche volk verwacht, indien het zich voor Gods Woord buigt.

(VG I, 1954:505)

Scholten heeft veel betekend voor de Nederlandse Christen Studentenvereniging (NCSV), het Nederlandse bijbelgenootschap (NBG) en vooral de reorganisatie van de Nederlandse Hervormde kerk. Deze activiteit begon met zijn lidmaatschap van de vereniging Kerkopbouw, waar hij met Noordmans én van de bruggebouwers was naar de vereniging Kerkherstel. In 1931 werd hij in opdracht van 'Kerkopbouw' voorzitter van een commissie die een nieuw ontwerp makte voor een kerkorde en daarmee in twaalf vergaderingen gereed kwam (Bartels 1946:76vv). Dit ontwerp werd door de Algemene Synode verworpen. Scholten werd nu voorzitter van een commissie die uit beide verenigingen was samengesteld. Het uiteindelijke resultaat, nl. het reorganisatievoorstel van 1938 werd opnieud verworpen. In 1942 werd hij voorzitter van de commissie 'Beginselen van kerkorde'. Scholten werd door de Duitse bezetter 'verbannen' naar Valkenburg in Zuid-Limburg. Later mocht hij dit oord verwisselen met zijn buitenhuis in Nunspeel, waar de commissie onder zijn leiding kon vergaderen. In 1944 werd het raport van de commissie het ontwerp kerkorde, aangeboden aan de synode en de voorstellen werden in 1945 in tweede lezing met grote eenstemmigheid aanvaard. In December 1945 werd hij door de synode benoemd tot voorzitter van de 'Commissie voor de kerkorde'. Scholten kwam plotseling te overlijden. Prof Berkelbach van der Sprenkel nam zijn plaats in als voorzitter. Helaas heeft Scholten zelf de voltooing arbeid aan de nieuwe kerkorde niet meer kunnen beleven.

Scholten was een fel tegenstander van richtingen. De gedachte, dat Christus gedeeld zou zijn, was hem een gruwel. Hij voelde zich zeer aangetrokken tot Karl Barth, maar hij behield zijn zelfstandigheid. 


\section{SCHOLTEN EN NOORDMANS}

Scholten is bijzonder geinteresseerd om de ontmoeting van recht en theologie (VG II 1938:288) en het is daarom niet toevallig dat hij Noordmans op zijn weg tegenkwam. Hij liet zich con amore engageren voor de arbeid van de reorganisatie van de kerk waarbij Noordmans ook zo aktief betrokken was. Scholten had een bijzondere waardering en een zeker respect voor Noordmans en hij behoorde tot diegenen die al vroeg het unieke theologische talent van Noordmans onderkende. 'Ik ben geen theoloog', zegt Scholten, 'Toch mag ik misschien op grond van mijn warme belangstelling in de theologie zeggen, dat ik in ons land geen theoloog ken, aan wiens oordeel ik zoveel dank als aan het uwe. Ik heb uw Herschepping nog niet geheel doorgewerkt. Het bevat compact en eenvoudig gezegd zo grote rijkdom dat het slechts langzaam kan worden bestudeerd. Ik kan alleen zeggen dat mij de lezing een voortdurende vreugde was' (1935-01-16). 'Nergens heb ik bij Nederlandse auteurs zulk een diepe behandeling der vragen gevonden als bij u' (1935-10-10). Eerder al verklaarde Scholten (1934-11-8): 'Ik heb in uw arbeid een sterke verwantsckap gevoeld met mijn eigen werk, uw oordeel daarover heeft voor mij een bijzondere waarde. Ik volg uw werk reeds geruime tijd met gespannen aandacht, zowel voor eigen geestesleven als voor de grondslagen van mijn werk - die toch tenslotte in de theologie liggen - heb ik er veel aan gehad.' Als Noordmans 70 jaar wordt schrijft Scholten heel persoonlijk

dat ik ervan overtuigd ben dat er in ons land geen is van zulk een betekenis voor de theologie, daardoor en voor de Kerk ook buiten onze grenzen en voor ons volk, als gij. Gij zijt niet altijd gemakkelijk te volgen, dat zal wel de oorzaak zijn dat dit niet altijd, dat het veel te weinig en veel te laat is erkend. De toekomst zal het, daar ben ik zeker van, uitwijzen. En ik wil er gaarne bijvoegen, dat het mij een vreugde is u ook persoonlijk te hebben leren kennen, zodat ik niet alleen door het lezen van uw werk, ook door uw omgang ben verrijkt.

(1941-07-18)

\section{GEEN FENOMENOLOGIE MAAR THEOLOGIE}

Prof $G$ van der Leeuw noemde Noordmans een onbewuste fenomenoloog. Noordmans wil dat niet vierkant tegenspreken maar vindiceert voor zichzelf de theologie en niet de fenomenologie.

Wat mijn pen in beweging brengt is niet de exegese pur sang, al wil ik - n'en déplaise Van der Leeuw - graag weten wat er precies staat. Het is ook niet een dogmatiek als zodanig, die de teksten in het don- 
ker zou willen zetten. Het is een geluid en een licht, waardoor en waarbij men in zekere mate de dingen kan horen en zien...Teksten spreken niet altijd direct, ofschoon ze dat ook kunnen doen. $\mathrm{Zij}$ stemmen soms samen of roepen dissonanten te voorschijn, waarbij het oor de menging moet weten te onderscheiden. $\mathrm{Zij}$ komen door allerlei medium tot ons, door schotten, muren, zolderingen. Zij dringen niet alleen door de oren, maar ook door de poriën binnen. De atmospheer kan er mee verzadigd zijn. Zij hebben hun uitlegging gehad in de historie en ze weten zich ook weer uit de geschiedenis los te maken. $\mathrm{Zij}$ scheppen de levensvoorwaarden voor ons geloof om ons heen en zij richten een rechtbank in ons binnenste op in het geweten. Zo staat het ook met het dogma, op zijn eigen wijze, weer anders dan met de teksten. Het dogma schijnt niet altijd als een ster, maar het is dikwijls ook aanwezig met een diffuus licht. En toch blijft onder dit alles de tekst een geluid en het dogma een licht. De uitlegging van de eerste blijft exegese en de toepassing van het andere theologie.

(VW 6, 192v)

Hoe scherp Noordmans ook kon waarnemen en hoe scherpzinnig hij de fenomena kon duiden, het ging hem om het verstaan van Gods openbaring. Dat is theologie.

Zoals wij zullen zien was ook voor Paul Scholten zo, dat wij alleen van teologie kunnen spreken als theologie van het Woord van God.

\section{DESCARTES EN DE KENNISTHEORIE}

Scholten schrijft na aanlijding van Noordmans' artikel over René Descartes (VW 4, 320-344):

Ik kwam er 'eerst gisteren toe uw artikel te lezen. Ik heb dit met grote belangstelling - als bij alles van uw hand - gedaan en heb er ook wel iets aan gehad voor mijn inzicht in Descartes, maar hoop mij er nog nader mee bezig te houden. Ik sta naamelijk tegenwoordig telkens voor de problemen der kennistheorie. Christenen zijn meest of naief-aristotelisch of kantiaans in hun kennisleer, dan wordt daar een afzonderlijk stuk over het geloof als iets daarvan losstaands aan toegevoegd. Ik meen, dat wij vanuit de bijbel christelijk ook iets over kennisleer moeten kunnen zeggen, maar het is mij nog erg schemerig wat. Om dat wat verder te zoeken had ik juist het voornemen om zodra ik tijd had me met Descartes, vooral met het cogito ergo sum 
bezig te houden. Daarbij zal ik zeker wat hebben aan uw opmerkingen.

In 1934 hield Scholten voordrachten te Leiden over Beginselen van Samenleving en hij zette in bij de vraag naar vastheid: 'De mens van de nieuwere tijd zoekt die zekerheid in zich zelf. Hij zelf, zijn ik, zijn eigen ervaren, daarop gaat hij ten slotte terug. Descartes' uitspraak, 'cogito ergo sum', was de afweer tegen de bodemloze twijfel, die ieder weten, die ten slotte het zijn zelf aantastte. Ik denk - mijn zijn is onbetwistbaar. Die uitspraak werd de grondslag van geheel de nieuwere wijsbegeerte' (VG I, 330). Na een uitgebreide passus over de plichtenleer van Kant komt Scholten bij Descartes terug en via hem bij Augustinus' '...cogito ergo sum'. Ik moet u nogmaal vragen u de betekenis daarvan voor te stellen. Het lijkt zo eenvoudig, niet meer dan een logische conclusie: leder die denkt bestaat, ik denk, dus ik besta. Doch het is anders bedoeld, het is de formulering van de zekerheid, die de grondslag is van ieder denken, dus ook van de logica. Ook de logica zou ons kunnen misleiden. Wij willen vaster bodem. Het is de muur, waartegen állen twijfel dood loopt. Men kan gaan twijfelen aan alles, aan de mogelijkheid iets te weten, onze zinnen kunnen ons bedriegen, ons denken ons op dwaalwegen bregen, alles, alles is wellicht illusie - doch er is één punt waar alle scepsis ophoudt en ophouden moet. Ik denk - ik ben' (VG I, 358v).

Scholten ziet bij Augustinus dezelfde methodische twijfel als bij Descartes al is er verschil. Bij Augustinus is er naast denken en zijn een derde. En dit derde deel van het ik wordt nu eens met 'velle', dan met 'amare' aangeduid. Augustinus is niet cen man van scherpe terminologie. 'Voluntas' word afgewisseld met 'amor' ook met 'dilectio'. Dit denken en dit zijn is handelen, willen, liefhebben, activiteit. Scholten is beducht voor de abstracties van Descartes en Kant. Zij is ook bij Augustinus te vinden, doch hem was het om het leven meer dan om het denken te doen - hij vult de abstractie met leven. Bij Kant en Descartes wordt het denken geisoleerd. De gereformeerde theoloog Voetius had daartegen reeds bezwaar gemaakt (Descartes Lettres II, 170). Gij neemt, zegt deze tegen Descartes, het 'cogito ergo sum' tot grondslag van uw stelsel, vanuit dat 'cogito' komt gij tot uw voorstelling 'heldere ideeën', van daar tot het hewijs van God's bestaan. In geheel die tussentijd, in uw denken van het ogenblik dat ge twijfelt tot uw conclusie, zijt ge zonder God, uw lezers, die uw betoog volgen en aannemen verkeren in het zelfde geval, dus zijt gij en zij verloren (VG 1, 360). Scholten spreekt hier over de stugge hardheid van de gereformeerde. 'Maar', zegt hij, 'heeft hij in het wezen der zaak niet gelijk? Het principieel terugtrekken van het ik op het denken alleen en een betoog van daaruit is het niet een verloochening van God en ook van die naaste? (VG I, 361). 


\section{AUGUSTINUS}

Scholten heeft steeds een bijzondere belangstelling voor Augustinus aan de dag gelegd. In zijn Beginselen van Samenleving sluit hij zich bij Augustinus aan:

[G]emeenschap is gemeenschap alleen, indien zij iets van de liefde in zich weet vast te houden. Een van de heel groten uit de geschiedenis, Augustinus heeft dit begrepen, toen hij voorstelde de 'civitas' - wat wij nog het best met burgerlijke gemeenschap, niet met staat vertalen - te definieeren als de 'coetus multitudinis realis, rerum quas deligit concorde communione sociatus' (De Civitate Dei XIX.24), vertaald: 'civitas' is het werkelijk samenzijn van een menigte, verenigd in de gemeenschap der harten van de dingen die zij lief heeft. Er is slechts 'civitas' als er is een gezamenlijke liefde.

(VG I, 342)

In deze voorstelling kunnen èn de strijd om het persoonlijk recht èn de strevingen naar gemeenschapsvormen haar adel hebben. Het vrijheidsrecht van onze tijd heeft historisch zijn grondslag in de gewetensvrijheid, het Caivinisme kan naast het liberalisme zich als zijn vader doen gelden. Laten wij dit goed vasthouden tegenover de grauwe macht der velen, die van gemeenschap spreken, maar eigen wil begeren op te leggen...En toch is de hunkering. Een hunkering naar een wàre gemeenschap. Om nog eens aan een woord van Augustinus te herinneren: 'remota justitia', zonder gerechtigheid, is de 'civitas' niet dan een roversbende.

(De Civitate Dei IV, 4)

Scholten heeft bijzondere waardering voor Noordmans' boek over Augustinus: 'Ik weet niet of ik u dat vroeger al eens gezegd heb, maar ik heb voor dat boekje een grote bewondering. Ik heb er niet alleen voor mijn begrijpen van Augustinus, maar voor inzicht in geschiedenis, in de kerk vooral veel aan te danken. Het geeft je een plaats waar je staan kunt als je over deze dingen nadenkt en opent dan uitzicht op uitzicht' (1937-08-09).

\section{SPANNING MET DE ETHISCHEN}

Noordmans en Scholten maakten beiden deel uit van het moderamen van Kerkopbouw. In de loop van de tijd ontstond er steeds meer wrijving tussen hen en de Ethische heren, of wel de 'Utrechtse kring' zoals Noordmans hen noemde: $H$ Th Obbink, A M Brouwer en M van Rhijn. G van der Leeuw, Groningen en Ph Kohn- 
stamm, Amsterdam, stonden daarbuiten. Argwanend gevolgd door Brouwer, voorzitter van Kerkopbouw, hebben Noordmans en Scholten baanbrekend werk gedaan voor het samengaan van Kerkopbouw en Kerkherstel, wat uiteindelijk het fundament heeft gelegd voor de totstandkoming van de nieuwe kerkorde. Brouwer verzet zich met alle heftigheid tegen leertucht. Snedig merkt Scholten op, dat hij vasthouden tegenover Brouwer thans noodzakelijk acht 'om geen voet te geven aan zijn bedenkelijke belijdenisleer. Deze mensen spreken over ons als voorstanders van de juridische leertucht, terwijl juist zij de belijdenis als niet anders dan juridisch kunnen zien' (1938-06-21).

De spanning leidt tot een breuk als Van Rhijn in het Algemeen Weekblad voor Christendom en Cultuur een artikel plaatst, 'Verontrustende verschijnselen', waarin Van Rhijn zich afzet tegen het reorganisatievoorstel en tegen de Barthianen: 'De geest van het Fascisme, dat om den mond slaat of afranselt, maakt zich van menige voorstander der reorganisatie meester...De heren combineerden "Het Woord" en de knuppel. Barth en Hitler.' Noordmans beklaagt zich bij Scholten: 'U zult het schandelijke artikel van prof van Rhijn in 't Algemeen Weekblad gelezen hebben. In 't bijzonder prof van der Leeuw en ik worden er blamerend - niet genoemd - maar met de vinger aangewezen...Op deze toer gaat het niet langer. We zullen een eigen organisatie nodig hebben en een eigen blad. Een herstel van de oude formatie lijkt mij, na dit artikel...uitgesloten' (1938-07-19).

Twee maanden later bericht Noordmans nà overleg met ds Zeydner en dr Koopmans over de affaire-Kerkopbouw (1938-09-16):

Voor een op-nieuw-in-zee-gaan onder de leiding Obbink-Brouwer voel ik hoe langer hoe minder. Brouwer heeft zich vastgewerkt in een positie, waaruit hij niet meer loskomt. Hij is gestrand op een theologische klip, omdat hij, geen stuurman zijnde, toch het roer in handen nam...Ik ben overtuigd dat een hergroepering moet plaats hebben in verband met de organisatie-beweging. In 't Oktobernummer van Onder eigen Vaandel geef ik...een artikel over die materie, waarin ik heb gezegd hoe ik mij dat denk...Wij zullen dezelfde mensen voor een deel, maar ook anderen, onder andere voorwaarden moeten samenbrengen...Daartoe hebben we een adempauze nodig om even tijd te hebben - ook geestelijk - om ons op de veranderde omstandigheden in te stellen.

Begin November komt Kerkopbouw nog samen. De persoonlijk kwesties vooral tussen Brouwer en Noordmans kwamen aan de orde. Noordmans verklaarde zich bereid in een persoonlijk onderhoud, in 't bijzijn van prof Obbink, zoveel mogelijk aan Brouwer tegemoet te komen. 'Na afloop had ik, ten huize van prof van Rhijn, 
in 't bijzijn van prof Kohnstamm, een vrij langdurig onderhoud, dat tot een bevredigende uitkomst leidde. Van Rhijn zal daaromtrent een korte mededeling doen in 't Algemeen Weekblad. Dit betekent echter niet dat ik weer als medewerker word ingeschakeld. Herhaling is in 't leven zelden of nooit mogelijk. Verzoening gelukkig wel' (1938-11-02).

\section{WOORD EN WERELD}

De breuk met de Ethischen bracht afstand tot het door de Ethischen gedomineerde Algemeen Weekblad voor Christendom en Cultuur en een direkt gevolg was de oprichting van een nieuwe periodiek. Scholten was de bezielende figuur achter het nieuwe tijdschrift Woord en Wereld, dat maar enkele jaren bestaan heeft en door oorlogsomstandigheden moest worden opgeheven. Scholten schrijft:

De bedoeling is een centrum te scheppen voor dieget.en, die op een of andere wijze de invloed der dialectische theologie hebben ondergaan (de naam Barthianen verfoeien wij) en die op grondslag van een hun aldus gefundeerde christelijke overtuiging de actuele vragen van staat en samenleving willen begrijpen. Het tijdschrift zal dus niet zijn uitsluitend theologisch, maar moet wel hebben principieel theologische grondslag. Het zal verder gewijd zijn aan vragen van staatsleer en politiek, maatschappijbeschouwingen en ethiek. Dit alles in zeer ruime zin genomen, dus ook kunst en wetenschap omvattend.

Er is Scholten veel aan gelegen om zich van Noordmans' medewerking te verzekeren. 'Wij hebben die medewerking broodnodig, omdat wij juist in u de aangewezen man zien om ten aanzien van de fundamentele grondslagen leiding te geven en omdat wij ook van uw kijk op de actuele vragen willen profiteren...Het zal wel niet nodig zijn hieraan toe te voegen, dat ik persoonlijk het zeer op prijs zou stellen, indien gij deze uitnodiging aanneemt. Wijs haar in elk geval niet direct van de hand' (1938-10-19).

Noordmans reageert enthousiast (1938-10-21):

Met grote belangstelling nam ik kennis van de inhoud van uw schrijven. (Het) lijkt mij van veel belang. Ik heb het ontbreken daarvan reeds geruime tijd als een ernstige leemte gevoeld... Of ik iets zou kunne geven van wat $u$ in dit opzicht van mij vraagt, zou ik van te voren niet gaarne zelf bevestigen. De vragen zijn bezig ons zo snel boven het hoofd te wassen, dat een oplossing hoe langer duidelijker in de 
hand Gods komt te liggen. Bijna van dag op dag is dat, in steeds sneller tempo, het geval.

Daags na de eerste redactievergadering schrijft Noordmans over de naam. Er is besloten tot de naam Dienst. "Het woord "Dienst" druk wel veel uit, maar als het daar zo alleen staat op de titelpagina van een tijdschrift, doet het toch wel heel kort en abrupt aan.' Noordmans pleit voor Woord en Dienst: 'Dit lijkt mij, als "dienst" gebruikt zal worden, nog het beste. De indruk, die deze combinatie wekt, is toch ernstig, religieus, bijbels...De beide woorden verklaren daarbij elkaar...lk geef u mijn meditatiën in de trein - die ik aan de koffietafel de spitsroeden van de critiek van m'n vrouw liet lopen - nog eens uitvoerig, omdat een titel, als uithangbord, lang niet onverschillig is' (1938-10-27). De volgende dag voegt Noordmans er aan toe: 'Heden verscheen een nieuw tijdschrift [van Senden] met titel: Idee en Mythe. Dus ook weer de copula "en". Daartegenover houdt Woord en Geest wel een bijbelse tegenhanger in. Verder zou het naast Woord en Geest, waarbij u vaste medewerker is, een breder blikveld betekenen; meer algemeen; minder theologisch, wat ook met de inhoud overeenkomt' (1938-10-28).

In zijn verantwoording namens de redactie schrijt Scholten: 'Een getuigenis van God's Woord willen wij geven...Wij willen ons afvragen hoe dat Woord moet worden begrepen, wat wij in gehoorzaamheid daaraan hebben te zeggen nu, hier in Nederland over de Kerk en over den Staat, over de samenleving, haar vorm en haar functies, in één woord: tot de Wereld' (Scholten 1939:1).

\section{DE KRONIEK}

Noordmans verzorgt als eerste de 'Kroniek' in Woord en Wereld. Zelf acht hij het 'genre Kroniek, dat mij 't beste ligt - de kroniek-essay' (1941-01-28). Scholten laat merken dat hij bijzonder ingenomen is met de wijze waarop Noordmans zijn kroniek heeft opgezet en daarmee voortgaat: 'Ge moet vooral deze rubriek zo persoonlijk houden als zij is. Dit is voor de kerk van belang' (1939-05-09). Als Stufkens de kroniek als zodanig, als vaste rubriek wil metamorfoseren, komt Noordmans daartegen op (1939-05-12):

Hij wilde een moment van verrassing daarin aanbregen, door onverwachte stemmen, zelfs buiten de redactie, daarin te later klinken. De kroniek was dan geen kroniek meer. Mijn opvatting is, dat in de kroniek God wel voor de verrassingen zorgt door de gebeurtenissen, die daarin opgetekend en gecommentarieerd worden. Maar dat overigens deze rubriek een genre is, dat continuïteit niet kan missen, zonder dat het karakter daarvan zoek raakt. Daarom sou ik u inderdaad 
willen voorstellen de zaak te laten, zoals die geregeld was. Het schrijven van de kroniek zou heel lastig worden, als daarin ook kleine stukjes van een andere hand voorkwamen, nl voor hetzelfde terrein. Wat een invallen van uzelf betreft, daartegen zou minder bezwaar zijn. In de eerste plaats, omdat u redacteur van de periodiek is. Maar allemeest omdat er homogeniteit bestaat, naar vorm en materie, tussen uw publicistische existentie en de mijne, ook bij verschil in bijzonderheden.

In geen geval wil Noordmans zich door anderen laten opdragen wat en hoe te schrijven. 'Vroeger reeds vond ik de wijze waarop Kraemer de leiding nam in de redactie, door voor de inhoud der artikelen een program op te stellen, samen met Stufkens, te ver gaan. Ik wens niet onder leiding te schrijven, maar te zeggen wat God mij ingeeft' (1945-12-31).

Scholten wil graag dat Noordmans in zijn kroniek ingaat op de synode-booschappen. Noordmans weigert, ook als Scholten opnieuw aandringt vanwege 'de omstandigheden waaronder' (1940-11-17). Hij heeft groot bezwaar tegen dit instituut, acht dit rooms en acht een synode niet bevoegd (1940-11-13) en voegt er dan aan toe: 'In deze omstandigheden moet ieder wandelen bij zijn eigen licht. De gemeenschap is sterker en nodiger dan ooit. Maar de zekerheid is mystischer dan anders. Men kan geen licht en geen olie van elkaar lenen' (1940-11-17).

\section{LITURGIE}

Scholten heeft met bijzondere interesse de polemiek van Noordmans en Van der Leeuw over de liturgie gevolgd (1939-07-26):

In de stilte der vacantie...heb ik behoefte gehad uw boek over liturgie nog eens goed door te lezen. Ik las het wel, maar uw werk eist altijd een terugkeren, bij eerste lezing pakt het slechts bij fragmenten. Nu ik dit gedaan heb moet ik nog eens uitspreken, dat Van der Leeuw toch eigenlijk aan alle principiële dingen is voorbijgegaan. Hij polemiseert voorzover hij zich aangevallen voelt, doet dit loyaal en soms sterk, maar het eigenlijke vind ik bij hem niet. Dat eigenlijke grijpt hij niet, omdat hem ontgaat wat het Woord is. Uw betogen over het Woord als de plaats van de ontmoeting met God, het Woord dat zich niet laat vangen in het pastoraat - zij zijn voor mij bij uitstek verhelderend geweest. Misschien juist daarom, omdat ik van nature een neiging heb tot al datgene wat Van der Leeuw aanprijst - wat toch alles een vooruitgrijpen is, dat ons niet is veroorloofd. Uw boek heeft 
mijn reformatorisch besef zeer versterkt. Niet wij brengen een offer maar het offer is voor ons gebracht - dat is de kern, die wij. zoals ge terecht zegt, moeten vasthouden.

Noordmans is verheugd met de gedachten die Scholten hem schreef naar aanleiding van de lezing van 'Liturgie' (1939-08-02):

Uit mijn antwoord aan Van der Leeuw...zult $U$ merken, dat ik mijn best gedaan heb de bespreking terug te voeren tot "het principiële" in mijn boek, waarover u schrijft. Het Woord als Reiziger en het Sacrament als Blijver; dat is de kern van mijn boek. Daarop is Van der Leeuw niet ingegaan en daarom heb ik dat met nadruk nog eens naar voren gebracht...Prof van der Leeuw zet het Woord achter preek en sacrament terug, als onderstelling, om er dan over te gaan philosopheren. Dat is de moderne Incarnatie-gedachte, waaraan Aalders, ofschoon meer gereserveerd, ook zijn hart heeft verpand. Calvijn dacht anders als hij zegt, dat Christus voor ons staat: 'evangelio suo vestitus' ( = in het gewaad van zijn evangelie). De kern van deze kern is dan weer de schrifturlijke offergedachte, dat het Offer in het Evangelie tot ons komt. Dit accepteert Van der Leeuw niet, maar de vluchtige wijze, waarop hij dat terzijde schuift, bewijst dat deze principiële dingen te weinig tot hem zijn doorgedrongen. Hij zit te vast in zijn liturgisch schema om er omniddellijk voldoende op te kunnen reageren.

Toch heeft Scholten een kritische vraag aan Noordmans en wel deze (1939-07-26):

Is de Kerk niet ook de plaats waar de gemeente aanbidt?...Dit punt komt naar mijn mening niet geheel tot zijn recht in uw boek. Het was wellicht niet nodig in het verband, maar het heeft wel recht op een plaats in de eredienst, zij het na het horen van het Woord en na het sacrament, doch naar mijn mening voor de handreiking. Ik schrijf u dit omdat ge er wellicht reden in vindt, als ge het onderwerp weer onder handen hebt, misschien wel in uw repliek op Van der Leeuw, er iets over te zeggen. Dit ook hierom, omdat ge als ge zo een enkele vingerwijzing geeft, ge het misverstand kunt wegnemen alsof ge zoudt menen dat de dienst, zoals hij thans in de Nederlandse Hervormde Kerk is, een heilig huisje zou zijn, waaraan niet mag worden geraakt. Immers het spreekt vanzelf dat deze traditie evenmin heilig is als de traditie van de Oude Kerk. Alleen we zullen wel moeten oppassen dat wij daar mee beginnen. Het wordt dan zo licht willekeur, daarin heeft Barth gelijk. Als wij eerst ons volledig onder het Woord stellen, 
als wij de Kerk, dus niet individueel, hier en daar een mens, daarvan getuigen op de 'wereldakker', dan kan in ons de behoefte komen in de dienst wijziging te brengen. Maar we moeten wel heel zeker zijn dat God dat wil. Voor mij is het alles nog veel te veel spel, een fraai, een vroom spel, maar spel.

Noordmans antwoord (1939-08-02):

Over de Aanbidding heb ik in mijn antwoord ook geschreven. Daarbij heb ik opgemerkt niet zo klaar te zijn, als Van der Leeuw mij voorstelt. Ik zie wel een gevaar in dat sterke centraal stellen van de aanbidding. ' $t$ Is, in de vorm waarin de Liturgische Beweging het uitoefent, zeer bepaald een novum. 't Hangt samen met de bovenbedoelde Incarnatie-theologie en met de idealistisch-ethische beschouwingen over de eredienst. Ik heb in mijn antwoord daarop gewezen en een vergelijking gemaakt tussen bidden en aanbidden. 't Laatste is toch niet minder dan ' $t$ tweede. ' $t$ Is persoonlijker, veiliger. Barth laat ergens in de Römerbrief de zonde geboren worden uit aanbidding van Eva voor God. De zondencatalogus der aanbidding is in ieder geval langer dan die van het bidden. Getuige de kloosterethiek. Bidden is ook, als ik het zo noemen mag, bijbelser. De tempelgebeden uit Lucas 18 geven geen aanbidding maar eenvoudig een gebed te beluisteren. Wanneer de aanbidding in de zin de Liturgische Beweging centraal werd, zou onze gereformeerde Dienst des Woords niet meer te herkennen zijn.

Daarmee is niet gezegd dat het moment der aanbidding aan het bidden vreemd zou zijn. Maar het praedomineert - althans hier op aarde - niet. Het gebed van het kind Gods tot de Vader blijft ook in de eredienst, wat de Duitsers een Bittgebet noemen. Het is een vragen; allereerst van vergeving der zonden; wat een al te directe adoratie van God uitsluit. Alleen de Heiligen kunnen regelrecht aanbidden. Zondaren zijn al bijna tevreden als ze bidden mogen. Ik vrees, dat de verborgen grond is, waarom de aanbidding in de eredienst, zoals de Liturgische Beweging die drijft, te veel spel blijft, zoals $u$ het ook noemt, en moet blijven. Bidden correspondeert met leven, zoals de Dienst des Woords dat ook doet. De aanbidding als centrum van eredienst maakt daarvan een afgesloten geheel. 


\section{DE BFOEFENING VAN HET KERKRECHT}

Scholten als scherpzinnig jurist en uiterst origineel in de rechtsvinding en Noordmans als even origineel theoloog en uitmuntend kenner van het grondvlak van de kerk hebben samen vele jaren geëxerceerd in het kerkrecht. Eerst in het kader van Kerkopbouw maar al heel snel deden zij een poging van daaruit om tot samenwerking met Kerkherstel te komen. Toen de toenadering eindelijk tot een accoord leidde, werd Scholten in 1937 voorzitter van de reorganisatie-commissie. Na verwerping van het reorganisatie-ontwerp-1938 met tien stemmen tegen en nege stemmen vó6r in de Algemene Synodale Commissie, waarvoor vooral de Ethischen verantwoordelijk waren, werden er nieuwe wegen gezocht. De kerk was niet echt vertegenwoordigd in de oligarchie van de negentien.

Noordmans gaat nu pleiten voor een brede Algemene Synode, de enige manier om het regime van de Ethische heren te doorbreken. De Algemene Synodale Commissie zou er voor moeten zorgen

om bij wijze van proef de hele kerk in een Brede Algemene Synode volgens ons art 63 Algemeen Reglement bijeen te brengen, voor eén keer; een soort kerkelijk congres. Daar zou de kerk functioneel en niet bestuurlijk vertegenwoordigd zijn. Dat ware een eerlijke kans aan het Ontwerp geven en de consideratiën beproeven aan een breed en kleurig staal van de nieuwe kerkorde. Parool zou kunnen sijn: de kerk op de tweesprong. En ieder zou mogen beginnen dat op zijn eigen wijze op te vatten. Het congres zou goed voorbereid moeten worde. De voorstanders van reorganisatie of liever de nieuwe kerk kan daar aanschouwelijk onderwijs geven. En de gevers van negatieve consideratiën zouden, of ze wilden of niet, tot tot positiviteit gedwongen zijn. Voor degenen, die vastgeraakt zijn, zoals prof Brouwer en anderen ware dit een weldaad. Ook de vrijzinnigen zouden, zonder vrees dat hun een haar gekrenkt zou worden, zich op de voordeligste wijze kunnen tonen. Dit zou 'fair play' zijn naar alle zijden. Wanneer de Synodale Commissie de consideratiën van 1427 tegenstemmers moet aanpassen aan de dode letter van het Ontwerp zal daar niet veel ven terecht komen. De aanpassing zal moeten plaats hebben 'al doende' onder het toepassen van art 63, waarin de kerk op haar breedst uitkomt.

Maar voorlopig blijft alle nog bij het oude. 'De afloop van de reorganisatie-aangelegenheden in de Synode is geweest als vanouds. De Synode zit en blijft zitten', verzucht Noordmans (1939-(08-12). 
De notulen van de Commissie voor de kerkorde, die onder lijding van Scholten in December 1945 met de werkzaamheden begon, zijn een verder 'Fundgrube' voor de exercities van Scholten en Noordmans en samen met nog vele anderen op het terrein van het kerkrecht. (Deze notulen zullen binnenkort uitgegeven worden.)

\section{IN DE OORLOG}

Als Woord en Wereld ophoudt te verschijnen, komt de redactie niet meer bijeen en is er geen concrete aanleiding meer om elkaar te ontmoeten. Scholten en Moordmans hebben beiden allang bedankt voor Kerkopbouw. Toch blijven zij niet alleen in schriftelijk contact, maar zoeken elkaar ook op in Laren (juli 41) en Hulshorst: '...uw prettig bezoek hier...' (1843-01-04) en '...zomer 1943...' (1944-01-25). In 1942 wordt Scholten door de bezetter als hoogleraar ontslagen en eerst naar Valkenburg (L) en daarna naar Hulshorst verbannen. Hoewel van alle practische arbeid afgesneden, blijft Scholten toch actief. Hij neemt nu het plan van Noordmans over, om naamlijk

de regeling van de samenstelling van de synode uit het ontwerp-1938 te lichten en dit stuk dan alleen in te voeren. later kan dan een nieuw samengestelde, andere synode, waarin de kerk werkelijk spreekt, over de brandende vragen van tucht, van verwijzing naar de belijdenis, van behandeling der 'schare' en wat er meer toe hoort, oordelen. Mijn vraag is nu: hoe denkt ge hierover?...Gij zoudt mij een genoegen doen mij uw oordeel mede te delen. Sinds het najaar hebben wij niets van elkaar bemerkt. Dat was in deze omstandigheden niet mogelijk. Toch had ik u gaarne weer eens ontmoet. Gaarne ook uw reactie op wat wij beleefde gehoort. Toch bleef in de geest ook de band met $u$. Hebt ge uw gedachten al eens laten gaan over de vraag wat de kerk, als eens de vrede zal zijn weergekeerk, te zeggen heeft?

Later vraagt Scholten Noordmans' visie op de Ontwerp-regeling. Noordmans ziet daarin veel goeds (1944-04-25):

Het voorziet in de impasse van een overgang, maar alle cauties, die wij in 1939 hadden aangebracht, blijven nu achterwege. Tegenover de mogelijkheid van een herhaling van 1886 heb ik steeds gemeend, dat daarvoor gewaakt moest worden. De actie-Kraemer is nu de enige cautie. Deze is inderdaad tegen een herhaling van 1886 zeer sterk gericht. De vrijzinnigen zullen waarschijnlijk meer vertrouwen stellen in deze levende zekerheidstelling dan in de reglementaire van 1938. 
Vroege was een grote synode voor hen steeds een schrikbeeld. Zij waren bang voor het losgooien van de kerk. Er is zeker verwantzchap tussen dit ontwerp en onze voorstellen van 1938; maar alleen in de bedoeling van de enkelingen onder de opstellers van het nu aan de orde zijnde.

De opzet is om te beginnen presbyteriaal. Maar dit kan evengoed dynamisch worden opgevat als de belijdenis op blz 9 . Eigenlijk nog veel eerder, omdat de kerkorde, ook volgens dit ontwerp, minder direct uit de Schrift is afgeleid dan de belijdenis. De werkmethode in Gemeenteopbouw is reeds episcopaal en niet presbyteriaal. Een kader wordt gevormd. Boodschappen worden aan vergaderingen voorgelezen, die dan weer kunnen uiteengaan. Kraemer vroeg op de Utrechtse predikantenvergadering als kenmerken 'statesmanship' en daadkracht. Nu is 'statemanship' in die zin wel het laatste wat de kerk is toe te wensen. Rome heeft zich misgaan aan 'statesmanship'. Dat hangt samen met een dynamische opvatting van de leer. Een dynamische leer is de keerzijde van een episcopale kerkorde. Als derde hoort daarbij een bewogen liturgie. Liturgie is dynamische leer. De Engelse kerk is steeds royaal in de leer, maar zuinig met de liturgie geweest. Bij de reformatie heeft de leer een groot stuk van de kerkregering overgenomen. De presbyteriale kerken werden geregeerd door de leer. Daardoor kwam de regering van Christus haar veel nader. De leer regeerde haar veel. De leer regeerde hen ook in hun huizen en niet alleen in de kerken. De roomsen erkennen nu, dat daarin een voordeel steekt. $\mathrm{Zij}$ geven de leken de bijbel. De pastoor kan zoek raken, de bijbel mider gemakkelijk. Tussen bijbel en leer hebben de oude protestanten nooit een strenge scheiding gemaakt. Maar tegenover de dynamische kerkregering van Rome, waarvoor Newman later de theorie heeft gegeven, verschijnen toch bijbel en leer bij eerste aanblik als statisch. Tegenover papale evoluties en ontaardingen stelt de presbyteriale huisman zijn: er staat geschreven. Pas daarna, heel voorzichtig, kan van dynamiek in de leer gesproken worden. Het eerste wat aan de leer opvalt, is de statiek. Door de leer heeft de protestant veel meer huiselijke en innerlijke godsdient dan de roomse. Volharden in de leer de apostelen is de vorm der gemeente. Deze brede en vaste basis van gemeeteleven moeten wij niet inruilen tegen een kerklijke staatkunde van episcopale aard. Voor de laatste zijn tijdelijk de voorwaarden aanwezig. Er is geen publiciteit. Maar daar- 
van mag gee misbruik worden gemaakt. Dat zal, naar wij hopen, niet zo blijven.

\section{NOORDMANS' OORDEEL OVER KUYPER}

Scholten stoot bij zijn studie op het kerkbegrip van Kuyper en diens tegenstelling tussen organisme en instituut (1943-01-04). Dit levert een zeer interessante uiteenzetting van Noordmans op (1943-01-09):

De beschouwing van geestelijke verschijnselen zoals kerk en wetenschap als organisme is een tijd lang zeer 'en vogue' geweest...De verschuiving, die daarmee in het calvinistische denken heeft plaats gehad, bleeft niet onopgemerkt. Ik denk bv aan Oud en Nieuw Calvinisme van ds C B Hylkema in 1911...In ieder geval kan men de toepassing van het begrip 'organisch' op geestelijke verschijnselen als kerk en wetenschap niet als een eenvoudig toepassing van een bijbelse figuur beschouwen. Het is een soort school, zoals er ook een 'historische' school geweest is. Daarbij zijn allerlei invloeden merkbaar geweest en het is werkelijk niet gemakkelijk precies te weten hoe dat zit ...Nu is Kuyper overigens ten opzichte van der kerk en in 't algemeen wel op zijn hoede voor 'Verflauwing der grenzen'. De kerk als organisme drijf bij hem haar wezen buiten de kerk als instituut...Deze laatste wordt aan alle kanten omspoeld door de uitingen van de kerk als lichaam van Christus, het leven gewekt door de wedergeboorte. De belangstelling, die Kuyper voor dat leven uit de wedergeboorte koesterde, is althans in haar uitbreiding over het hele levensterrein en wat betreft haar intensiviteit wel modern te noemen tegenover de reformatoren. Wie de grote redevoeringen van Kuypers grote tijd kent, zal dit moeten beamen. Daarin bracht hij ten gehore hoe in de christelijke eeuwen het christelijke leven, naar Gods raad, als een zich verbreden en verdiepende stroom, van Oost naar West rolt. In zijn Gemeene Gratie heeft Kuyper daarvoor ook de theorie zoeken te geven. Hij zat met zijn hart veel meer bij de kerk als organisme, dan bij het instituut. Aan de geïnstitueerde kerk heeft Kuyper geen rechte impuls weten te geven. Hij heeft de Hervormde kerk uiteengerukt en de Gereformeerde Kerken bleven een fragment. Hij was niet vroom genoeg om kerkvorst te kunnen worden. - Bavinck laat de kerk als organisme en die als insitituut meer dooreenlopen en is daarin meer gereformeerd op gewone wijze. Hij vermijdt de scheiding van beide opvattingen der 
kerk. Hij loopt minder gevaar dan Kuyper om door hypertrofie van de kerk als organisme het leven van de kerk als instituut te verburgerlijken en ineen te doen schrompelen. Beiden, Bavinck en Kuyper, kenden de kerk als instituut goed genoeg, om aan de ergste gevaren van een organische beschouwing het hoofd te kunnen bieden. Ook Kuyper kon dat wel. Hij bleef theoloog en werd geen bioloog.

Wat mijn eigen opvatting nu betreft, geloof ik dat wij met het begrip 'organisch' heden ten dage erg voorzicht moeten omgaan. Het gereformeerde leven heeft altijd wel gehad wat Kuyper er ook wel mee bedoelt: het had veel kerk buiten de kerk, in huis en hart. Maar dit behoeft toch niet al te 'organisch' te worden opgevat. Dit gebied heeft ook zijn instellingen, analoog met die van het kerkelijk instituut, ofschoon er verschil blijft. Maar het leven, dat Kuyper 'organisch', wedergeboren noemt, moet onder beslag van het Woord blijven. Het blijft van boven geboren worden. De geestelijke gaven zijn charismata en komen niet vanzelf uit het christelijk leven op. Het Woord dat tot leven wordt is in de gelovigen aan bederf onderhevig en dit is het geval naarmate het verder van Woord en Sacramenten verwijderd raakt.

\section{NOORDMANS' LMMERITAAT}

Noordmans werd gedwongen in de oorlog met emeritaat te gaan. Hij heeft zich heftig tegen 'het verplichte emeritaat' verzet en beklaagt zich meermalen bij Scholten (1944-01-25; 1944-04-25). De Synode bood emeriti de mogelijkheid als hulpprediker aan te blijven, maar Noordmans vond deze mogelijk geen 'fiere finale' van een lange ambtsbediening, en wenst in elke geval 'deze niet als een gunst maar als een rect'. De kerkeraad van Laren heeft zijn predikant deze gunst slechts eenmaal voor zes maanden verleend:

Ik ben sedert 30 December hulpprediker. Deze functie loopt 30 juni af...Zo ben ik ook geen kerkeraadslid meer. Ik woon de classicale vergaderingen niet bij...Dit aftreden valt mij niet zo heel gemakkelijk en maakt het laatste halfjaar van ambtsbediening, waarin mijn ambt toch al reeds gereduceerd was, tot het moeilijkste van de hele tijd en ook wel van mijn hele leven. Ik hoop er donr heen te komen, maar het heeft mij wel nedergebogen en mijn gezondheid heeft een tijd lang gevaar gelopen...De Synode...heeft een herbenoeming in de han- 
den van de kerkeraad gelaten. Dat wil in dit geval zeggen de kerkeraad zonder de predikant. Deze kerkeraadsleden, boeren, die men bijna een generatie had getrouwd, gedoopt, begraven, moesten beslissen of men zou aanblijven of niet. De ambtelijke verhouding degradeerde in die van een ambtenaar tot zijn bestuur. Dit bestuur maakte in vele gevallen, ook in mijn geval, met verwaarlozing van piëteit, gebruik van zijn macht. En zo viel de steun van het ambt, die bij ons werk onontbeerlijk is, weg. $U$ weet, hoezeer ik mij in de reorganisatie-beweging daartegen heb verzet. Mijn laatste ervaring heeft mij tenzeerste in mijn op dit punt bevestigd.

(1944-04-25)

\section{NA DE OORLOG}

Direct na de bevrijding worden allereerst de persoonlijke ervaringen gedurende het laatste oorlogsjaar uitgewisseld. Daarna komen de algemene indrukken. Noordmans heeft in Laren, zo dicht achter de ljsellinie, het nodige meegemaakt:

De pastorie is een puinhoop; de kerk dakloos en zonder toren. Het dorp een halve ruïne door driedaags granaatvuur...Persoonlijk kwam ik in groot levensgevaar... Wij moeten sedert 4 November telkens verhuizen, thans voor de derde maal. Wij hebben nauwelijks pied a terre...Wij hadden een moeilijke winter door isolement...Wij hopen dat de opheffing van het isolement ons zal tegemoet komen. Onder de bestaande omstandigheden is het nauwelijks mogelijk aan de eerste levenseisen te voldoen. Alleen de voedselnood was hier niet nijpend. Mijn bibliotheek ligt ergens op zolders en werd geteisterd door granaatvuur. Zal ik ooit nog weer een studeerkamer hebben kunnen raadplegen? God weet het. Mijn vrouw en ik slaan ons er door, zo goed en zo kwaad als dat gaat. Wij zien de toekomst onder getemperd licht. Zie hier een droog relaas van onze fata', aldus Noordmans onmiddellijk na de capitulatie.

$(1945-05-06)$

Het antwoord van Scholten volgt een maand later (1945-06-05):

In het land is het op alle gebied een chaos. De beproevingen zullen nog wel zwaar zijn - materieel en geestelijk. Er is arbeidsschuwheid en verwildering. De kerk wacht een ongelofelijk zware taak, moge God haar de kracht verlenen die te volbrengen. Zouden wij nog met 
Woord en Wereld weer kunnen beginnen? Nu zeker niet, maar later? Is er nog eenheid en stuwkracht genoeg? We zullen Koopmans daarbij bitter missen...Het is voor theologie en kerk een zwaar verlies. En onder de figuren achter ons tijdschrift zal de leegte zijn; ook Eykman, aan wie ik persoonlijk door sterke banden van vrienschap verbonden was, is weggenomen. Het zal nog wel een tijd duren voor we weer eens rustig kunnen praten. Er moet in ons land veel gedaan worden en toch is bezinning naast deze tijden van daden zo hoog nodig. Ik hoop dat gij daaraan nog mee zult kunnen arbeiden en God u de kracht geeft uw denken vruchtbaar te maken voor ons volk.

En zes maanden later (1945-12-09):

Hoe gaarne zou ik eens met u praten over al wat in de wereld en in de kerk geschiedt. Hoe gaarne had ik u dan ook mijn medeleven uitgespreken in de ramp die u persoonlijk getroffen heeft en u uit Laren heeft verdreven. Aan uw eigen en altijd tot de diepte gaande beschouwing had ik mij graag gesterkh, al denk ik wel, dat er verschil tussen onze opvattingen gebleven zou zijn. Ik weet niet precies hoe gij er tegenover staat, maar over de opening van de Generale Synode heb ik mij diep verheugd, ook over haar werk tot heden. Ik zelf was bij de bidstond en bij de ontvangst der vertegenwoordigers van de buitenlandse kerken. Niet geheel duidelijk is het mij wat ge meent, als ge schrijft dat ik tegenover Kraemer niet geheel mijzelf ben gebleven. Ik ben zeer bevriend met hem, heb voor zijn werk in de kerk in de algemeen grote bewondering, maar ik heb, geloof ik, ook tegenover hem mijn eigen kritisch oordeel niet opzij gezet...Stellig ben ik historischer en traditioneler ingesteld dan $u$, maar ik meen dat er tijden zijn, waar God door die tradities heen breekt. Wat er waardevol in was blijft toch wel, komt terug. En zo'n tijd beleven wij, naar mijn vaste overtuiging, thans. Moge God ons in die brandende kolk gebruiken.

\section{BEZWAREN TEGEN DE ACTIE-KRAEMER}

Noordmans vindt daarin aanleiding om nog eens uitvoering zijn bezwaren tegen de actie-Kraemer, $z$ i een ondermening, een politieke actie, te uiten, hoewel hij eerbied betuigd voor de persoon van Kraemer en voor de buitengewone gaven, die God hem geschonken heeft. 'Hij is iemand die geschiedenis maakt. Maar daarom juist moet men toezien, een fout, die Kraemer maakt, heeft gevolgen.' 
Ons predikanten-corps ken ik wel een weinig. Het leent zich in de laatste jaren gemakkelijk voor een actie. Ineens zijn ze weer allemaal gelijkgeschakeld. Het ambt wordt daarbij gesaeculariseerd. Het is geen schildwacht voor de eeuwigheid, zoals Calvijn het uitdrukte, maar 'doet ergens aan mee'. Nu is er in Gravemeyer een officiële propagandist benoemd, die automatisch is uitgenodigd bij iedere kerkelijk vergadeing. Men heeft, ter Synode, deze benoeming incidenteel genoemd, maar daarmee is de zaak niet opgehelderd...Nu gaat het er in onze tijd om, met alle krachten, ook op ongewone wijze, de chaos meester te worden. In zoverre mag alles incidenteel heten...De kerk in haar geheel kan zich bv geen 5 jarenplan veroorloven. Mott stelde ca 1911 het parool op: Christianisering van de wereld binnen deze generatie. God heeft daarop geantwoord met het jaar of de jaren 1939-1946, de ruwste openbaring van heidendom, die de wereld gekend heeft. Als ik daarom van een politieke beweging spreek, bedoel ik in de eerste plaats kerkelijke politiek. Maar als de kerk zelf van statesmanship gaat leven, dan wordt zij ook met de staat gelijkgeschakeld. Zij gaat zich mengen in de praktische politiek, geeft koloniale adviezen. De Synode is blijkbaar ten opzichte van dat laatste reeds op haar hoede geweest. Dit is te prijzen. Want als zij tot een 'rechter of scheidsman van deze dingen' (Luk 12:14) wordt, verliest zij haar onschendbaarheid. De actie-Kraemer kan uitlopen op een avontuur, waarbij de kerk op gevaarlijke wijze wordı betrokken in wereldse aangelegenheden.

Noordmans heeft hier zeer scherp de dingen en mogelijke ontsporingen aangevoeld. Maar ook binnen de kerk ziet Noordmans bezwaren (1945-12-31):

Kraemer wil in de kerk 'zijn gang gaan' en dat mag niet. Dan ontstaat er een beweging, die...roofbouw pleegt op de potentiële vermogens der kerk. Zij leidt dan tot een snelle, wat overspannen ontwikkeling, waarbij lastige hindernissen als bv het dogma in looppas worden genomen. Mijn opmerking...bedoelde te zeggen, dat wij in 1938 anders stonden. Wij zijn gelikwideerd door de oorlog, dat is door God. Maar dat verplicht ons niet om zonder kritiek te aanvaarden wat er voor in de plaats kwam. 


\section{TENSLOTTE}

Het is boeiend om te zien hoe deze twee grote en belangrijke figuren, Paul Scholten en Oepke Noormans, beiden zeer geïnteresseerd in de ontmoeting van theologie en recht, in hoge achting voor de ander en met behoud van eigen zelfstandigheid met elkaar omgingen en hoe zij hun verantwoordelijkheid ten opzichte van de kerk verstonden en in praktijk brachten. Zij hebben elkaar onmiskenbaar beïnvloed al is dat niet precies na te trekken ook al vanwege het fragmentarische van de nagelaten stukken.

Scholten werd na de oorlog voorzitter van de Commissie voor de nieuwe kerkorde en hij heeft Noordmans daar ook in gehaald, maar helaas, lang hebben zij in deze commissie niet kunnen samenwerken, want 1 Mei 1946 stierf Scholten op reis naar zijn dochter in Canada. (Zie over Scholten: Wiarda 1950/1951:61-173; Emmen 1950/1951:173-180; Langemeijer 1951:97-100, 109-112; Landsman 1951:552555.)

\section{Iitteratuur:}

Bartels, H 1964. Tien jaren strijd on een belijdende kerk. Den Haag.

Bregstein, M H 1945/1946. In memoriam prof mr P Scholten. Rechtsgeleerd Magazijn Themis.

Emmen, E 1950/1951. Recht, volk en kerk. Wending, 173-180.

Landsman, F H 1951. Het recht van de kerk. WPNR 5314, 552-555.

Langemeijer, G E 1951. Scholtens verzamelde geschriften. WPNR 4180/4184, 97$100,109-112$;

Noordmans, O 1978. Verzamelde Werken. Kampen.

Scholten, P 1949/1951. Verzamelde Geschrifien. 4 delen. Zwolle.

--. 1939/1949. Woord en Wereld. Nijkerk.

VG 1, [1949], 1954. Verzamelde geschrifien, 4 delen, samengesteld door Scholten, G J, Scholten, Y \& Bregstein, M H. Zwolle.

VG II, 1938. Kerk. Rede over de reorganisatie der Nederlandse Hervormde Kerk gehouden ter predikantenvergadering, Utrecht.

VW 6, 1986. Litungie in de crisis. Kampen.

Wiarda, J 1950/1951. Recht en geweten. Wending, 61-173. 